\title{
A novel closed system bubble column photobioreactor for detailed characterisation of micro and macroalgal growth
}

Holdt, Susan Løvstad; Christensen, L.; Iversen, J. J.L.

Publication date:

2013

Document Version

Publisher's PDF, also known as Version of record

Link back to DTU Orbit

Citation (APA):

Holdt, S. L., Christensen, L., \& Iversen, J. J. L. (2013). A novel closed system bubble column photobioreactor for detailed characterisation of micro and macroalgal growth. Abstract from 21st International Seaweed Symposium, Bali, Indonesia.

\section{General rights}

Copyright and moral rights for the publications made accessible in the public portal are retained by the authors and/or other copyright owners and it is a condition of accessing publications that users recognise and abide by the legal requirements associated with these rights.

- Users may download and print one copy of any publication from the public portal for the purpose of private study or research.

- You may not further distribute the material or use it for any profit-making activity or commercial gain

- You may freely distribute the URL identifying the publication in the public portal

If you believe that this document breaches copyright please contact us providing details, and we will remove access to the work immediately and investigate your claim. 


\title{
A novel closed system bubble column photobioreactor for detailed characterisation of micro and macroalgal growth
}

\author{
Holdt $\mathrm{SL}^{1 *}$, Christensen $\mathrm{L}^{2}$, Iversen $\mathrm{JJL}^{3}$ \\ 1 The Seaweed Network in Denmark, Kirkebroen 23, DK-2650 Hvidovre, Denmark, \\ susan@akvakultur.dk \\ ${ }^{2}$ Chr. Hansen A/S, Culture Production Denmark, Sdr. Ringvej 22, DK-4000 Roskilde, \\ Denmark \\ ${ }^{3}$ Sdr. Boulevard 296B, DK-5000 Odense C, Denmark
}

Growth of the marine microalgae Tetraselmis striata Butcher and macroalgae Chondrus crispus Stackhouse was investigated in batch cultures in a closed system bubble column photobioreactor. A laboratory cultivation system was constructed that allowed on-line monitoring of temperature, $\mathrm{pH}$ and dissolved oxygen tension and was intended for characterization of photoautotrophic growth. Regulation of temperature was done by cooling and carbon dioxide additions regulated $\mathrm{pH}$. The carbon dioxide addition rate was used to optimize irradiance and thereby optimizing growth conditions. Photosynthetically produced oxygen was catalytically removed from the closed system by addition of hydrogen over a palladium catalyst to avoid photorespiration and to quantify oxygen production. In addition, the bubble column photobioreactor was well suited for cultivation of algae due to fast gas to liquid mass transfer $\left(\mathrm{k}_{\mathrm{L}} \mathrm{a}\right)$ and fast mixing provided by split and dual sparging. Specific growth rates (SGRs) were measured using both off-line and on-line measurements. The latter was possible, because linear correlation was observed between carbon dioxide addition and optical density, which proves that carbon dioxide addition may be used as an indirect measurement of biomass (x). The slope of the rectilinear fit of $\ln (\mathrm{dx} / \mathrm{dt})$ as function of the time (t) then revealed the SGR. This allowed on-line determination of the SGR, and these determinations revealed detailed information about changes in growth with up to three different SGRs in the different batch cultures of both micro and macroalgae. The algal SGR is normally considered to be constant. The maximum SGRs found by on-line determination were $0.13 \mathrm{hr}^{-1}$ for $T$. striata and $0.12 \mathrm{~d}^{-1}$ for C. crispus. During batch cultivation growth stoichiometry was determined and photosynthetic quotients and carbon mass balances were used to validate the system. We have developed a system and presented some data handling tools that provides new information about the growth kinetic of algae. 